SERI/TR-231-2685

UC Category: $61 \mathrm{C}$

TECHNICAL AND ECONOMIC EVALUATION OF MACROALGAE CULTIVATION FOR

FUEL PRODUCTION

Daniel A. Feinberg

Susan M. Hock

April 1985

Prepared under Task No. 4513.20

Solar Energy Research Institute

A Division of Midwest Research Institute i617 Cole Boulevard

Prepared for the

U.S. Department of Energy

Contract No. DE-AC02-83CH10093 


\section{ABSTRACT}

The potential of macroalgae as sources of renewable liquid and gaseous fuels is evaluated. A series of options for production of macroalgae feedstock is considered. These options include nearshore (for Macrocystis), floating adjacent and nonadjacent (for Sargassum), plus bay/estuarine and land-based options (for Gracilaria and Ulva). The production option with the lowest feedstock costs is the adjacent strategy for Sargassum, with a cost of $\$ 48 /$ dry ash-free metric ton (DAFMT) based on currently sustainable yields, and a potentially achievable cost of \$24/DAFMT, based on improved yields. The estuarine option produced costs for Gracilaria and/or Ulva close to those of Sargassum: \$54/DAFMT currently, with \$27/DAFMT achievable with improved yields. The landbased system cannot produce macroalgae feedstock below \$13I/DAFMT, even with much higher yields than the nearshore systems. Because of their high carbohydrate content, the fuel products for which macroalgae are most suitable are methane and ethanol. Fuel product costs were compared with projected fuel costs in the year 1995. At currently sustainable yields, Sargassum, Gracilaria, and Ulva could be competitive sources of methane; with yield improvements, Macrocystis could as well. For the production of ethanol, only Macrocystis and Gracilaria offer competitive production potential, and then only if improved yields can be achieved. 


\title{
TECHNICAL AND ECONOMIC EVALUATION OF MACROALGAE CULTIVATION FOR FUEL PRODUCTION
}

\author{
Daniel A. Feinberg \\ Susan M. Hock \\ Solar Energy Research Institute \\ Golden, Colorado 80401
}

\section{I.0 INTRODUCTION}

The concept of farming marine macroalgae provides a significant opportunity for renewable fuel production. Marine biomass has been a commercially valuable resource for centuries, primarily for the production of chemicals such as agar, carrageenan and alginates. The Chinese have also developed a substantial industry of cultivating certain macroalgae for food. Energy production from marine biomass has been supported by governmental and industrial groups for many years.

Offshore Macrocystis farms have been conceived as multi-purpose entities, serving for chemical, aquaculture, fisheries, and energy production. Several of these concepts have been tried, including the Offshore Test Platform (OSTP) experiment designed by General Electric Company during 1978-1980. Numerous design problems prevented the collection of yield data (Tompkins 1980), and the subsequent shift of interest towards nearshore (depths less than 60 feet) production concepts. Nearshore farms and farm development can proceed more quickly than offshore farms with lower costs and earlier commercialization.

This paper reviews and analyzes the economics of fuel production from several combinations of macroalgal species, production concepts, and fuel conversion processes. A previous study (Ryther, 1984) screened over 50 macroalgal species, the most promising of which are included in this analysis. All of the production concepts considered are to be located in shallow, nearshore, and protected coastal ocean areas. Information is lacking on how much nearshore area is available for cultivation and how legal and coastal environmental constraints might limit the development of the technology, however the amount of land area available has been estimated to be 3,300 square miles off the Florida coast, and 750 square miles off the California coast (Bird, 1984). Additional land area exists along the gulf coast states and Hawaii. Several fuel conversion processes have been analyzed to convert the macroalgal feedstock to either methane or ethanol fuel products.

The Gas Research Institute (GRI) is currently investigating the use of nearshore concepts for the production of methane (Bird, 1985), and much of this analysis is based on their work. The Solar Energy Research Institute has supported an evaluation of land based systems (Ryther, 1984) for intensive culture of macroalgae to produce high value products. This analysis will consider the merits of each of the proposed concepts discussed below to provide a preliminary screening tool to guide future development efforts. 


\subsection{BASIC CONCEPTS OF MACROALGAE PRODUCTION}

A macroalgae energy system consists of two basic processes: the cultivation of macroalgae for biomass production and its harvesting, and the processing of the macroalgae feedstock into a gas or liquid fuel. This section deals only with the first step which consists of planting, growing and harvesting the kelp feedstock. The species of macroalgae chosen for this analysis were selected based upon potential high yields, chemical composition, and growth requirements. A general discussion of species characteristics and production concepts is presented below.

\section{I Macroalgal Species}

Different species of macroalgae present varying attributes from the fuel production perspective. An ideal species would produce high yields of biomass with desirable chemical composition, and would thrive over a wide range of habitats. Historically, the species chosen for cultivation have been selected for their high-value products, such as Laminaria and Porphyra which are cultivated in China and Japan for food, Eucheuma which produces carrageenan in the Phillippines, and Gracilaria grown in Taiwain (Chiang, 1981).

Of the species which grow in abundance in U. S. coastal waters, two basic morphological forms exist: benthic, and floating. The benthic species grow on the bottom, and can be either attached or unattached. Floating species do so because of gas bladders.

The species selected for the analysis include Macrocystis, a large brown algae which grows attached off the coast of California, Sargassum also a brown algae, which grows floating in tropical waters, and Gracilaria (red) and Ulva (green), benthic species which grow unattached in the bottoms of shallow embayments. Macrocystis, or Kelp, is the largest known marine plant. Kelp is highly developed and consists of a holdfast for attachment, a stipe or stem, and fronds. Kelp grows up to a foot a day, is usually found in waters 20-60 feet deep, and is currently being harvested for alginates. Sargassum grows in warmer waters and floats due to bladders that form from the stalk. Gracilaria and Ulva can be grown over a wider range of habitats due to a broader temperature tolerance, and are found in abundance along the east coast of the U.S. and the Gulf of Mexico.

Yields have been established for each of the species previously mentioned. Sustained yields are always lower than short-term yield figures. Short-term yield figures are intended to show the potential of the species (Table 1. ) 
Table 1. Yield Data from Macroalgae

(Dry ash free tons/ac/yr)

Short Term Long-Term (sustained)

Macrocystis

40-60

10

Sargassum

35

10

Gracilaria (non intensive)

25

10

Ulva (non intensive)

25

15

Gracilaria (intensive)

Ulva (intensive)

45

30

Source: Bird 1985

Yields are a function of the genetic growth potential of the plant, the nultritional state of the plant, the light regime (depth of planting), water turnover rate and plant density.

\subsection{Cultivation Techniques}

A brief discussion of the strategies for cultivation of aquatic species on the scale required for fuel production is necessary at this point. The Gas Research Institute (GRI) initiated the research and development of two nearshore concepts, while SERI/DOE continued investigations of concepts that cultivated benthic species of macroalgae. The distinctions between the strategies are due primarily to the characteristics of the species being cultivated. Figure 1 shows the location and depth range for each type of cultivation scheme relative to the shoreline. The discussion of algal morphology presented in Section 2.1 has provided a basis on which the most appropriate strategies for each algal species can be selected. In general, a variety of nearshore schemes, plus a land-based scheme, are felt to be most applicable for cultivation of macroalgae feedstocks; another option, offshore cultivation, is not considered, as it was determined not to be economically favorable (Tompkins 1980).

Several nearshore concepts have been envisioned for the cultivation of the species of macroalgae selected, based on the resources available, as well as the characteristics of the organisms. Four basic strategies can be identified for nearshore macroalgae cultivation which include: 1) Nearshore kelp, 2) Floating, both adjacent and non-adjacent to the shore, 3) Bay/Estuarine, and 4) Land-based.

In the nearshore Kelp production concept (Figure 2), juvenile plants from a kelp nursery would be planted in appropriate densities for maximum yields. The plants would be fastened to anchor lines from tugboat barges. Once the plants were mature, they would be cropped by kelp harvesting boats several times per year. The boats might also be capable of shredding and pumping the resulting kelp slurry to a transport barge, from which it would be transported to the fuel production facility. Residues from digestors or fermentors would be returned to the kelp beds periodically as fertilizers. 


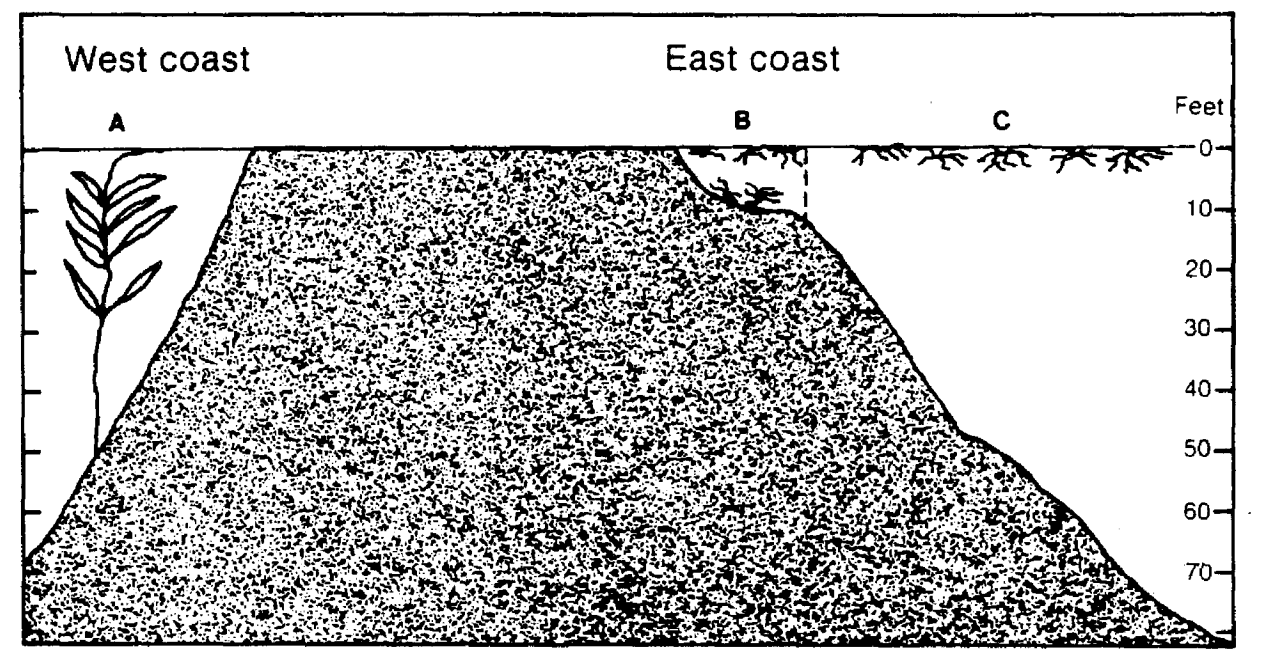

Production concepts are related to depth and the morphological form that can grow' in the habitat.

\section{Area:}

A - Macrocystis, an attached form, requires moving water, and suitable substrates of less than 60 feet.
B - The estuarine and adjacent concept, require protected, shallow areas of less than 10 feet for cultivation of nonattached benthic types.

$C$ - The nonadjacent floating concept can occupy open, deep areas of the continental shelf.

Figure 1. Location and Depth Range of Aquatic Species Cultivation Options 


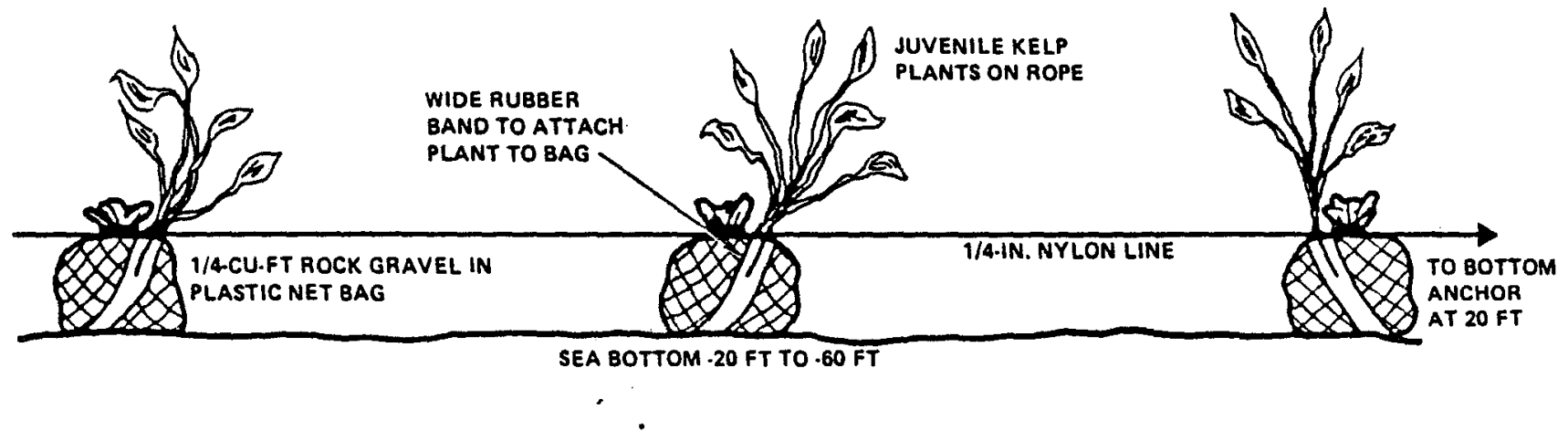

Figure 2. Typical Kelp Planting Scheme Source: Brehany, 1983 
The floating concept has the potential for producing the greatest quantity of biomass, due to a very large resource base. A floating species of macroalgae, such as Sargassum, could be contained by large booms in open areas of the sea. A boom-winch harvestor system (Figure 3 ) has been proposed to collect the biomass. If the area is close enough to the coast so that the harvestor is land based, the concept is known as adjacent. Alternatively, production areas offshore where the harvestor would have to be located on a platform or barge are known as nonadjacent. Harvested algae could be converted to fuel gas or alcohol, and residues from digestors or fermentors would be used to fertilize the plants. The primary culture management strategy would be to maintain an optimal plant density for production. Coastal areas off Florida, the Gulf states, California and Hawaii are potentially suitable for this type of macroalgal production.

The bay/estuarine culture would utilize protected areas of water less than 10 feet in depth to cultivate benthic macroalgae such as Gracilaria or Ulva. Plants of the red alga Gracilaria are used in some Asian countries as food; however, the major use of Gracilaria is as a raw material for agar which has numerous applications in the food industry. Culture of Gracilaria in tidal areas began in Tiawan in 1962. In 1972 there were 600 acres of farms commercially successful under cultivation (Shang, 1976). Seeding would be accomplished by fragmenting and then distributing the thalli into the bay. As is the case with all macroalgae concepts, fermentations are proposed for fuel conversion, and residues from digesters or fermenters would be used to fertilize the plants as with the other concepts. When the plant biomass reached harvest size, harvest barges, as were utilized during World War II in Florida for the harvest of Gracilaria, would harvest the biomass and return a portion of the thallus as seed for the next production cycle. Potentially, areas in Florida, eastern coastal states, Gulf states and Hawaii would be applicable to this type of production.

The land based concept would require intensive cultivation in raceway channels, with either a "V" shaped cross section or a perpendicular wall with a single sloping bottom. The algal biomass is kept in suspension by compressed air (Huguenin, 1976). Intensive algal cultivation requires both energy and nutrient inputs, and thus higher yields would be required to be economically feasible. Such production concepts are applicable to either coastal areas or possibly desert areas with available saline water. The species which are most applicable to land based cultures include Gracilaria and Ulva.

Of the four concepts, GRI has initiated development of the nearshore kelp, and floatingSargassum concepts. Considerable progress has been made in the establishment of sustainable yields with kelp, as well as a complete engineering feasibility study. The Sargassum work is just beginning and data on sustainable yields should be available by the end of the year. The SERI/DOE program has developed a large data base on the biology and production dynamics of Gracilaria and Ulva. Both species would be applicable to a bay-estuarine concept, although no research has yet been done in the United States to establish sustainable yields in the bay/estuarine environment. The land-based concept for macroalgae is at a similarly early stage of development.

As discussed above, the technologies for harvesting the biomass from all four production schemes are known or are conceptualized. These processes will require modification for increased efficiency and subsequent demonstration. The biomass slurry that is harvested consists of about $90 \%$ water - this would probably require additional de-watering before it would be suitable for fuel processing. 


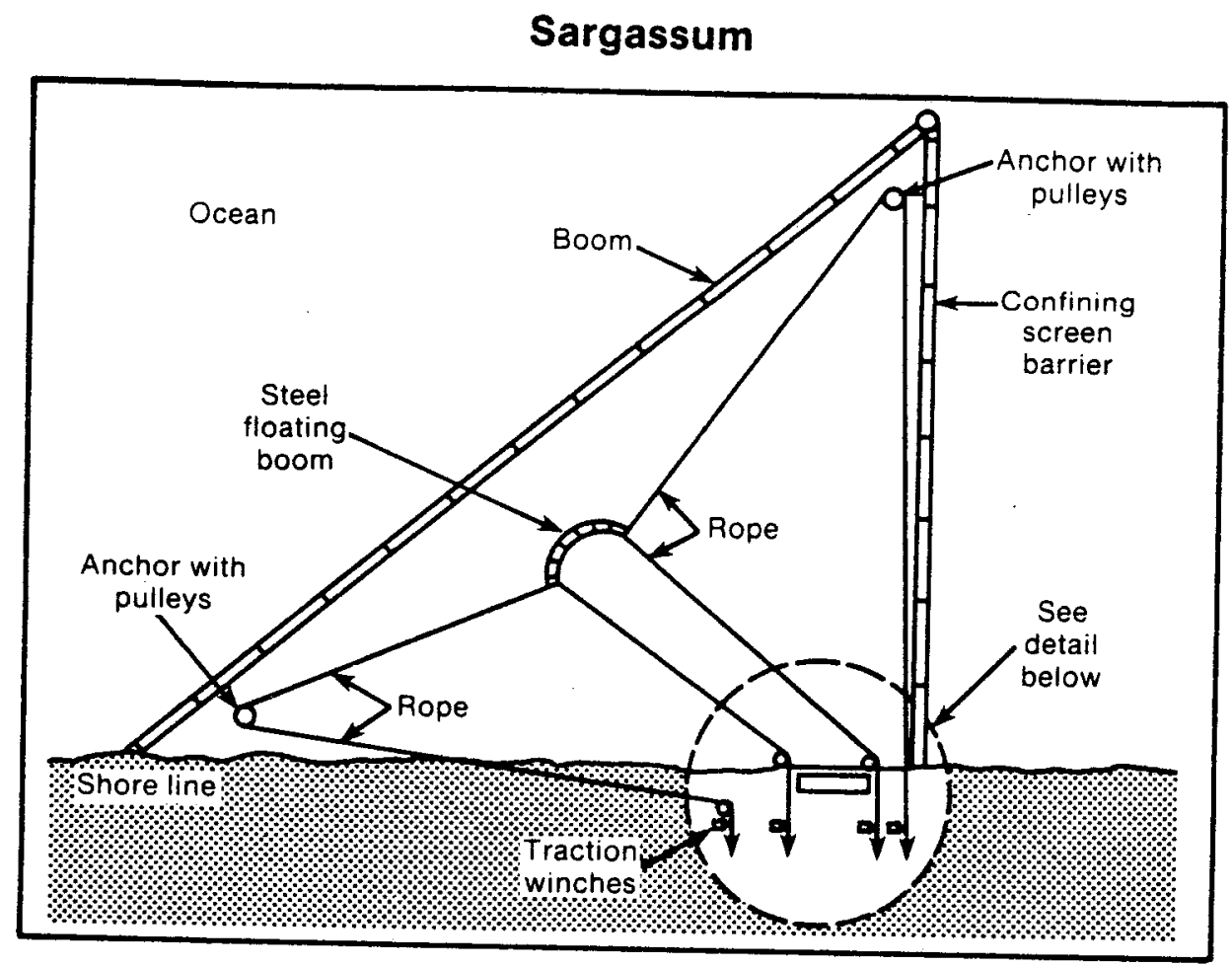

Floating Sargassum is confined within a barrier for cultivation.

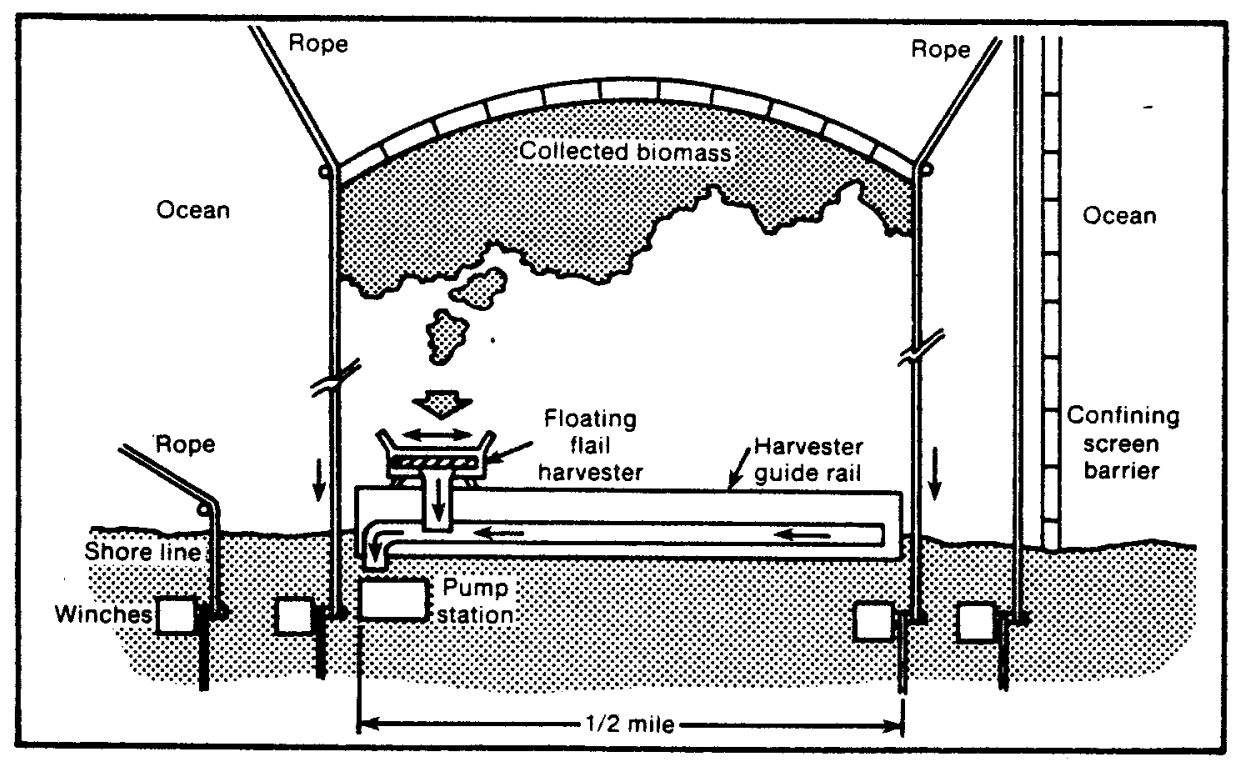

A boom-winch harvesting system is used to collect the floating biomass.

Figure 3. Active Boom - Winch Harvestor Concept Source: GRI 


\subsection{Selected Concepts for Evaluation}

The four production concepts described in section 2.2 were used for this analysis. Figure 4 depicts the relationship between the macroalgal species and the cultivation strategies that were selected. This section will describe each strategy in greater detail, and present the costs associated with each that are used for the economic analysis. The analysis has been made for both existing commercial systems (state-of-the-art) as well as experimental systems being considered for eventual commercialization (researchimproved). Several case studies were made for each concept, which examine the effects of facilities improvements and yield improvements on the biomass feedstock production economics.
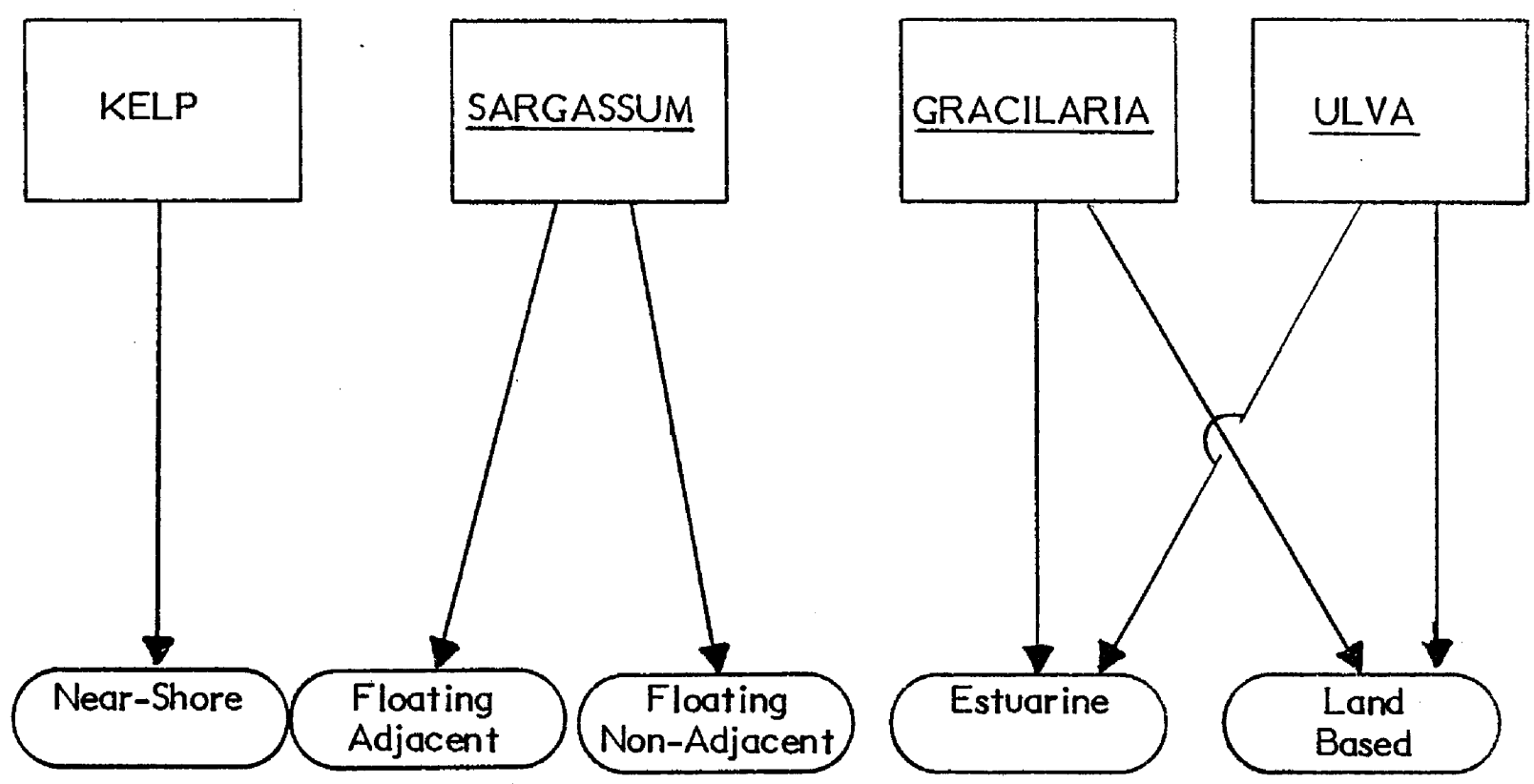

Figure 4. Selected Macroalgal Species and Production Schemes 


\subsubsection{Nearshore Kelp}

The near shore Kelp concept is based on the investigations of the Gas Research institute (Bird 1984). The Ralph M Parsons Company prepared a system study under contract to GRI (Brehany 1983) which proposed both a buseline and an advanced concept. These concepts were further refined by GRI (Bird 1984), and it is these updated system conceptualizations that are reviewed here.

The updated facilities follow the basic production scheme described in Section 2.2. The farm would be artificially planted over an area of 5342 hectares, at densities of 988 and 2470 plants per hectare for the baseline and advanced systems, respectively. The farm is expected to yield 22 to 34 dry ash free metric tons of biomass per hectare per year for the baseline system, and 50 dry ash free metric tons per hectare for the advanced system.

The harvesting system would consist of a special harvesting vessel that would cut and collect the Kelp, shred it into a pumpable slurry, and pump it in to a tug-attended barge for transport to the shore facility dock. The baseline facility would require 2 harvesters, 6 barges, and 4 attendant tugs, while the advanced facility requires one additional tug. A kelp slurry processing facility would be located on shore close to the farm.

The total estimated capital costs for the planting and harvesting system are $\$ 54,000,000$ (1982\$) for the baseline facility, and $\$ 68,000,000$ (1982\$) for the advanced system. The annual operation and maintenance costs would be $\$ 2,700,000$ and $\$ 2,900,000$ for the two systems; and the annual fuel costs would be $\$ 1,200,000$ and $\$ 1,400,000$. The capital investment includes $\$ 39$ million for planting and $\$ 15$ million for harvesting for the baseline facility, and $\$ 45$ million and $\$ 23$ million for the advanced facility.

The case studies that were investigated for this concept are outlined in Figure 5. Two yields were selected for the baseline facility, and one more optimistic yield chosen for the advanced case.

Species

Production Scheme

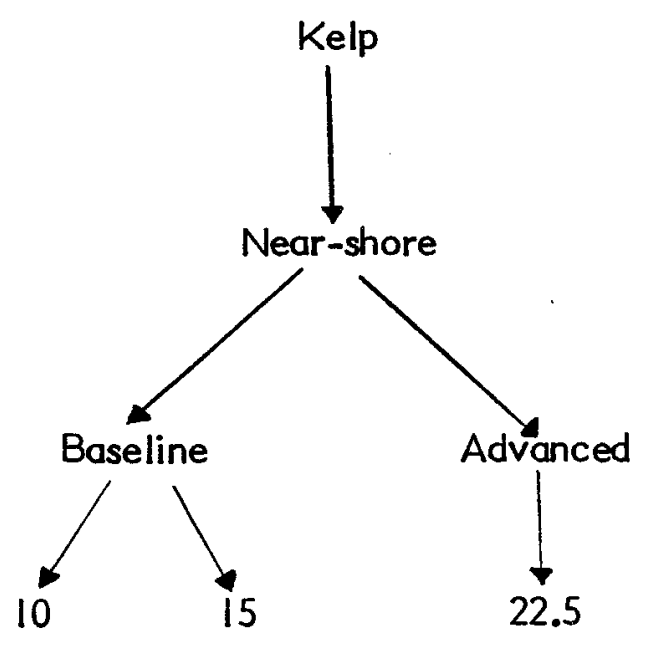

Yield, DAFT/acre

Figure 5. Nearshore Kelp Case Studies 


\subsubsection{Floating Sargassum}

It will be recalled that a floating adjacent and a floating nonadjacent option were examined for Sargassum. The facilities are based on concepts provided by GRI, and drawn from previous studies of water hyacinth cultivation systems (Bird, 1985), since it is assumed to have similar growth and harvesting requirements.

The floating adjacent concept is based on a design for an advanced water hyacenths system that directly abuts the shoreline. This system covers 13,206 acres, and for the purposes of this study, the yield is assumed to range from 22.4 to 44.8 dry ash free metric tons per hectare.

The floating non-adjacent facility is based on a baseline water hyacinths cultivation system modified for a marine environment. The facility would include an enclosed containment system that could be placed off shore (in $30 \mathrm{ft}$ water depths) to form a floating macroalgal crop to be harvested with boats. This concept is sized at 18,428 acres, with the same assumed yields as the shoreline adjacent system. GRI is currently developing a design to incorporate a boom winch type of system to be used in these offshore modules which should reduce harvesting capital and O\&M costs.

The total estimated capital cost for the floating adjacent farm is $\$ 34,900,000$, with an annual operations and maintenance cost of $\$ 1,356,000$, and annual fuel costs of $\$ 561,000$. The costs for the non-adjacent farm are higher, at $\$ 43,843,000$ capital, $\$ 5,232,000$ annual O\&M, and $\$ 2,393,000$ for fuel.

The case studies for both the adjacent and the nonadjacent Sargassum farms are presented in Figure 6. As can be seen in the figure, each facility type was investigated over a range of three yields.

Species

Production Scheme Floating Adjacent
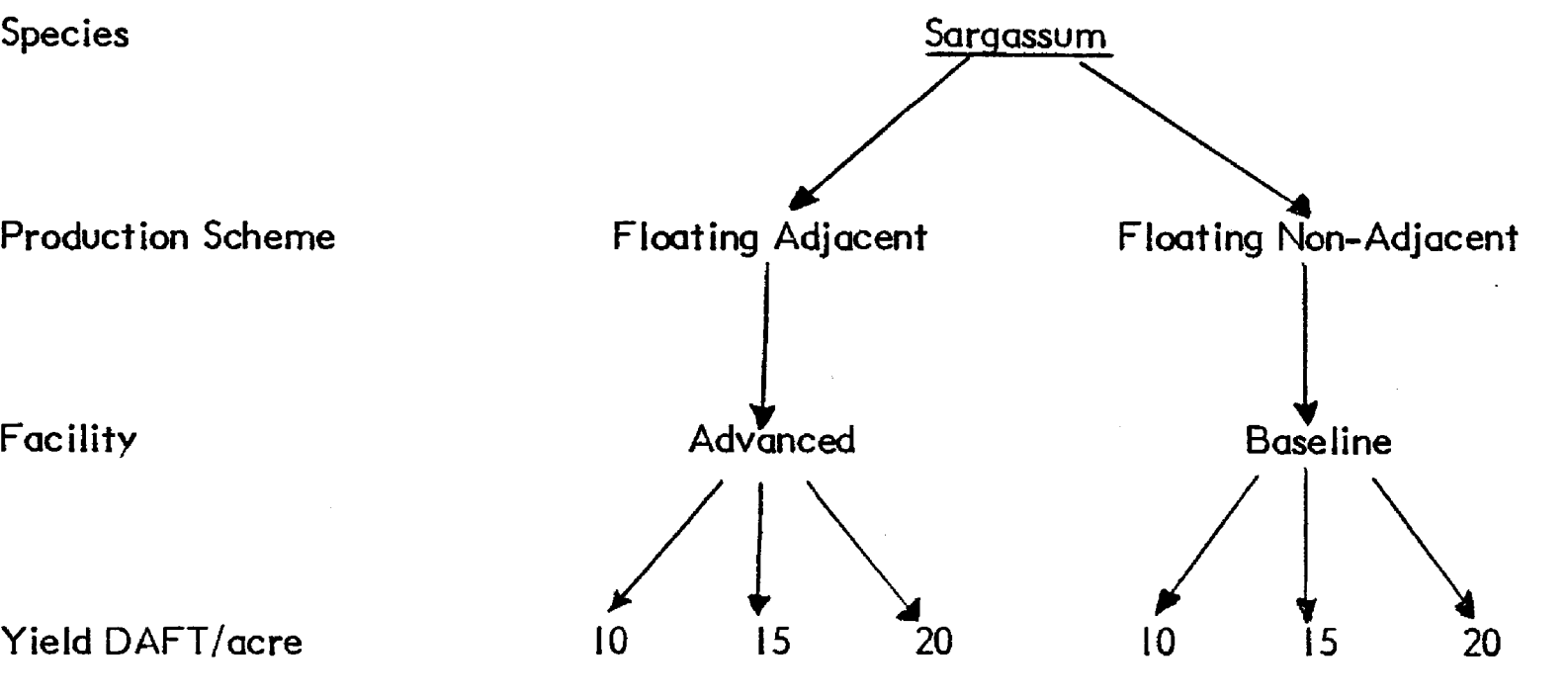

Figure 6. Floating Sargassum Case Studies 


\subsubsection{Estuarine Gracilaria/Ulva}

Gracilaria and Ulva have been considered together for the estuarine concept since their production requirements and yields are very similar.

This analysis of Gracilaria (or Ulva) cultivated in partitioned estuaries is based on cost figures provided by GRI, which derived them from a paper by Shang (1976).

Either Gracilaria or Ulva would be grown as free-floating plants within a partitioned estuarine system, similar to shrimp cultivation in Ecuador. This type of system, sized at 5344 hectares, would experience greater rates of water exchange than the Taiwanese pond culture described by Shang (1976), therefore higher yields might be expected.

The total capital cost for the pond system described by Shang is $\$ 18,279,000$, which we used as the base case. A study was performed by Gulf Stream Agar, Inc., (Benton, Travis) for GRI to determine the actual facility costs for an estuarine system. Their results indicate a much lower capital investment requirement of $\$ 10,000,000$ which is used in this analysis as a sensitivity case. The annual operation and maintenance cost for the base case is $\$ 2,700,000$, and the annual fuel cost are $\$ 1,200,000$. (These are the same values assumed for the baseline Kelp concept). The Benton study assumes a lower O\&M cost, since fewer laborer are required for an estuarine system, and union labor is not necessary as was assumed for the Kelp cultivation in California. Hence, the sensitivity cases assume only $\$ 2,000,000$ for O\&M costs.

Figure 7 outlines the case studies for this concept. Two facility types, the base case and the reduced cost $(45 \%$ reduction in capital cost) case, are examined. The reduced cost case is also made for a $50 \%$ increased yield.

Species

Production Scheme

Facility

Yield DAFT/acre

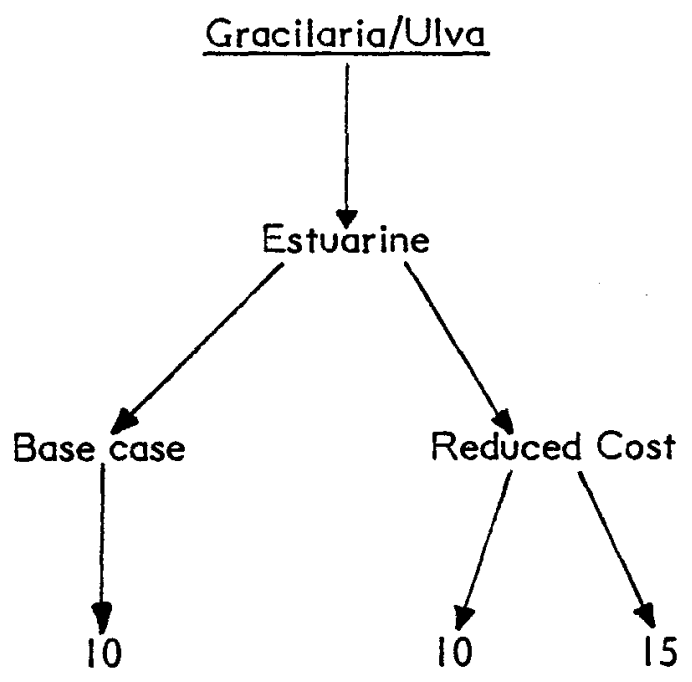

Figure 7. Estuarine Gracilaria/Ulva Case Studies 


\subsubsection{Land Based Gracilaria/Ulva}

An alternative method to the estuarine concept for producing biomass from Gracilaria or Ulva is to cultivate the macroalgae in land-based systems. This analysis is based on a study performed for SERI by the Harbor Branch Institution (Ryther, 1984). This concept is not dependent upon ocean water for its nutrient supply, and thus can be located on land, utilizing saline waters from sources such as underground acquifers.

The Gracilaria or Ulva would be grown in channels or raceways on land. The culture is maintained at a density of approximately two kilograms wet weight per square meter. The macroalgae is mixed and rotated by compressed $\mathrm{CO}_{2}$ from pipes distributed throughout the system, and is fed nutrients at regular intervals.

The incremental biomass is harvested at regular intervals to maintain an optimal yield. Saline water is pumped through the channels at a nominal rate of .I turnovers per day. Under these energy-intensive conditions, the yield of Gracilaria or Ulva is expected to be higher than that obtained in marine environments. This analysis assumed a yield of 54 DAFMT/hectare. The facility cost represents a 100 hectare system. A boom winch harvesting system similar to that used in water hyacinth systems is to be utilized to collect the yield.

The costs for land-based systems are in general much higher than for the other near shore concepts, due to the capital investment for pond construction, and the higher costs for operations such as pumping, mixing, and supplying nutrients. The base case facilities cost includes $\$ 2,970,000$ for capital investment, which covers equipment cost for pumping and aeration, land cost, pond construction, plumbing, and harvesting. The harvester cost was assumed to be $15 \%$ of the total capital investment. The annual fuel cost of $\$ 140,000$ represents fuel for pumping and aeration, and the O\&M cost of $\$ 570,000$ includes carbon and nutrients cost, maintenance, and labor. Increasing the pumping rate to .5 turnovers per day causes an increase of $\$ 292,000$ in capital costs for more equipment, and a fuel cost increase of $\$ 60,000$ a year. The assumption of $50 \%$ nutrient recycle cuts the nutrient costs in half, reducing the O\&M costs by $\$ 77,000$.

Five cases were investigated for this concept, to study the effects of increased costs due to a higher water turnover rate, decreased costs due to recycling $50 \%$ of the required nutrients, and the impact of increasing the yield to 78.45 DAFMT/hectare. These cases are depicted in Figure 8.

Species

Production Scheme

Facility

Yield DAFT/acre

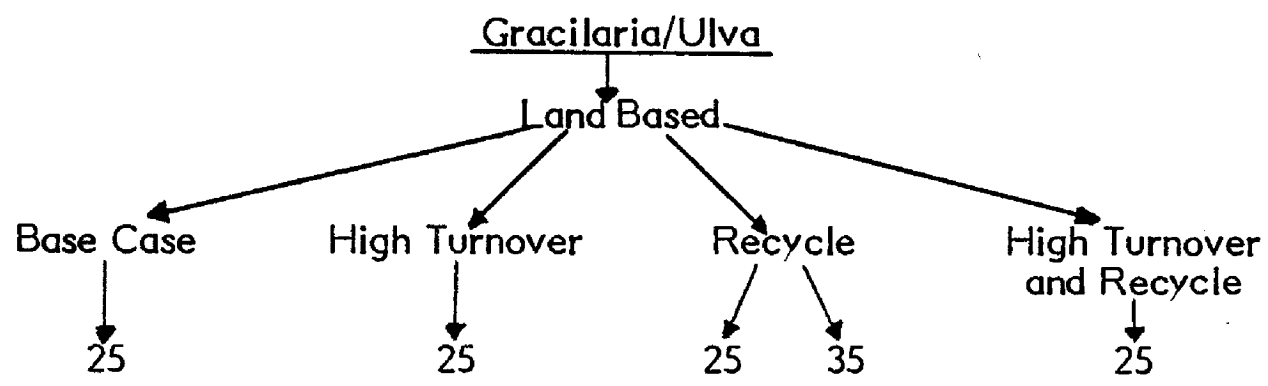

Figure 8. Land Based Gracilaria/Ulva Case Studies 


\subsection{MACROALGAE PRODUCTIONECONOMICS}

A series of production cost estimates have been developed for each case study discussed in Section 2. An economic levelized cost model was used to determine the cost of producing the biomass feedstock. The model, described in detail in Hill et al (1984), determines the macroalgae feedstock production costs based on levelized production costs for each case study.

The economics of production were determined for each case study for each macroalgal species, based on the costs presented in Section 2. Recall that the costs are given for a base case and for cases that represent changes in facilities (and associated costs) and changes in yields. The remainder of this section reviews the costs of each case study, and presents the resulting feedstock production economics.

The cost of the macroalgal feedstock is based on the life-cycle cost of production. It is comprised of the initial capital costs and the annual operation and maintenance and fuel costs anticipated over the lifetime of the facility. The financial assumptions used in this analysis are listed in Table 2. These assumptions represent the financial requirements for a privately owned industry. All rates and costs are given in real dollars, that is, no inflation has been considered. The cost are given in 1984 dollars, and the assumed startup date is 1995.

\section{Table 2. Financial Assumptions}

Base year for constant \$

Year for investment outlay

Year for cost information

Year of first commercial operation

Book life

Tax life for depreciation

Rate of return on debt

Rate of return on common stock

Rate of return on preferred stock

General inflation

Capital cost escalation rate

Fuel escalation rate 


\subsection{Feedstock Costs}

The feedstock costs represent the cost of producing the algal biomass and transporting the wet slurry to the shore for subsequent processing into fuel products.

\subsubsection{Nearshore Kelp}

The major assumptions and costs of the nearshore Kelp production concept, as well as the results of the economic analysis are presented in Table 3. The case identified in Table 3 as Baseline is based on a kelp yield of 22.4 dry ash-free metric tons (DAFMT) per hectare per year (10 DAFT ac $\mathrm{yr}^{-1}$ ). With a capital investment of $\$ 54$ million and annual operating costs of $\$ 3.9$ million, the total feedstock cost is estimated at $\$ 83.64 / D A F M T$. An intermediate case was then considered where a $50 \%$ yield increase has been achieved at essentially the same cost; this case gives a feedstock cost of $\$ 55.79 / D A F M T$. Finally, in the most advanced case, with planting density increased from the initial 988 plants per hectare to 2470 (thus increasing the yield to 50.4 DAFMT ha $\mathrm{yr}^{-1}$ ), the cost is reduced to $\$ 44.32 / D A F M T$. In the advanced case, the $25 \%$ higher capital costs and slightly higher operating costs are more than overcome by more than doubling the yield. The baseline case discussed above represents current state-of-the-art yields, but the other two cases could be demonstrated as sustainable within the next few years. 
Table 3. Near-shore Kelp Production Costs

\begin{tabular}{|c|c|c|c|}
\hline Case & Kelp - 1 & Kelp - IA & Kelp - 2 \\
\hline $\begin{array}{l}\text { Facility Size } \\
\text { (Hectares) }\end{array}$ & 5342 & 5342 & 5342 \\
\hline $\begin{array}{l}\text { Yield } \\
\text { (DAFT/acre) } \\
\text { (DAFMT/hectare) }\end{array}$ & $\begin{array}{c}10 \\
(22.4)\end{array}$ & $\begin{array}{c}15 \\
(33.6)\end{array}$ & $\begin{array}{c}22.5 \\
(50.4)\end{array}$ \\
\hline $\begin{array}{l}\text { Total System Yield } \\
\text { (DAFMT/yr) }\end{array}$ & 119,734 & 179,491 & 269,237 \\
\hline $\begin{array}{l}\text { Capital Investment } \\
\left(1982 \$ \times 10^{6}\right)\end{array}$ & 54 & 54 & 68 \\
\hline $\begin{array}{l}\text { Annual Fuel Cost } \\
\quad\left(1982 \$ \times 10^{6}\right)\end{array}$ & 1.2 & 1.2 & 1.4 \\
\hline $\begin{array}{l}\text { Annual O \& M Cost } \\
\left(1982 S \times 10^{6}\right)\end{array}$ & 2.7 & 2.7 & 2.9 \\
\hline $\begin{array}{l}\text { Feedstock Cost } \\
(1984 \text { \$/DAFMT })\end{array}$ & 83.64 & 55.79 & 44.32 \\
\hline \multicolumn{4}{|l|}{ Case Descriptions: } \\
\hline $\begin{array}{c}\text { Kelp - 1: Based on GRI updated } \\
\text { plants/hectare. }\end{array}$ & baseline & facility, planting & density of 988 \\
\hline \multicolumn{4}{|c|}{ Kelp - IA: Same as Kelp - 1, with higher yield } \\
\hline $\begin{array}{c}\text { Kelp - 2: } \begin{array}{l}\text { Based on GRI updated } \\
\text { plants/hectare. }\end{array}\end{array}$ & advanced & facility, planting & density of 2470 \\
\hline
\end{tabular}




\subsubsection{Floating Sargassum}

It will be recalled that a nearshore/adjacent and a nearshore/nonadjacent option were examined for Sargassum. Yields and costs for various cases of the two options are shown in Table 4. Facility size for the adjacent option was 5340 ha, the same as for a kelp facility, while for the nonadjacent option a size of 7460 ha was used. For both cases a yield range of 22.4 to 44.8 DAFMT ha ${ }^{-1} \mathrm{yr}^{-1}$ was examined. Capital costs were $\$ 34.9$ million in the adjacent scheme vs. $\$ 43.8$ million in the nonadjacent scheme, an increase of almost $30 \%$. Operating costs would increase even more drastically, to $\$ 6.6$ million from \$2.0 million. Both of these increases are accounted for by the greater distance from shore: construction costs increase with distance, and transportation of feedstock from the water to the shore serves to increase fuel costs. As a result, the baseline systems (with yields of 22.4 DAFMT ha $\mathrm{yr}^{-1}$ ) would have costs of $\$ 48.25$ and $\$ 80.37 / D A F M T$ for the adjacent and nonadjacent schemes, respectively. In the advanced cases, the costs would be $\$ 23.95$ for the adjacent system and $\$ 40.19$ for the nonadjacent system. Although the nonadjacent system has higher costs, it has the potential to utilize a much greater resource base.

For the adjacent system, over $50 \%$ of the cost is contributable to capital costs, while for the non-adjacent concept the largest cost component is the operating and maintenance expense.

\subsubsection{Bay/Estuarine Gracilaria or Ulva}

These two species have been considered together, and their feedstock production costs are at this point estimated to be equal. An estuarine system would have a facility size of 5340 ha, equal to the adjacent option. Three cases were considered (Table 5): a baseline case with a yield of $22.4 \mathrm{DAFMT} \mathrm{ha}^{-1} \mathrm{yr}^{-1}$, an intermediate case with reduced capital (from $\$ 18.3$ to $\$ 10.0$ million) and operating costs (from $\$ 3.9$ million $/ y r$ to $\$ 3.2$ million), and an advanced case, which includes the reduced costs plus a yield improvement to 33.6 DAFMT ha $\mathrm{yr}^{-1}$. Feedstock production costs drop from the baseline value of $\$ 53.92 / D A F M T$, to the intermediate value of $\$ 41.17$, and finally to the advanced value of \$27.45. Again, the baseline case represents the state of the art, but the intermediate and advanced cases are well within the range of achievable technologies.

In both the base case and the reduced capital cost case the highest contributor to production cost is the annual operations and maintenance cost. 


\section{Table 4. Floating Sargassum-Production Costs}

\begin{tabular}{|c|c|c|c|c|c|c|}
\hline Case & Sarg-IA & Sarg-IB & Sarg-1C & Sarg-2A & Sarg-2B & Sarg-3C \\
\hline $\begin{array}{c}\text { Facility Size } \\
\text { (Hectares) }\end{array}$ & 5347 & 5347 & 5347 & 7461 & 7461 & 7461 \\
\hline $\begin{array}{l}\text { Yield } \\
\text { (DAFT/acre) } \\
\text { (DAFMT/hectare) }\end{array}$ & $\begin{array}{c}10 \\
(22.4)\end{array}$ & $\begin{array}{c}15 \\
(33.6)\end{array}$ & $\begin{array}{c}20 \\
(44.8)\end{array}$ & $\begin{array}{c}10 \\
(22.4)\end{array}$ & $\begin{array}{c}15 \\
(33.6)\end{array}$ & $\begin{array}{c}20 \\
(44.8)\end{array}$ \\
\hline $\begin{array}{l}\text { Total System Yield } \\
\text { (DAFMT/yr) }\end{array}$ & 119,773 & 179,659 & 239,693 & 167,126 & 250,680 & 334,253 \\
\hline $\begin{array}{l}\text { Capital Investment } \\
\left(1982 \$ \times 10^{6}\right)\end{array}$ & 34.9 & 34.9 & 34.9 & 43.8 & 43.8 & 43.8 \\
\hline $\begin{array}{l}\text { Annual Fuel Cost } \\
\left(1982 \$ \times 10^{6}\right)\end{array}$ & .56 & .56 & .56 & 2.4 & 2.4 & 2.4 \\
\hline $\begin{array}{c}\text { Annual O \& M Cost } \\
\left(1982 \$ \times 10^{6}\right)\end{array}$ & 1.4 & 1.4 & 1.4 & 5.2 & 5.2 & 5.2 \\
\hline $\begin{array}{l}\text { Feedstock Cost } \\
\text { (1984 \$/DAFMT) }\end{array}$ & 48.25 & 32.17 & 23.95 & 80.37 & 53.59 & 40.19 \\
\hline
\end{tabular}

Case Descriptions:

Sarg - 1: Based on a design for an advanced water hyacinths system that directly abuts the shoreline. A), B), \& C) represent variations in yield.

Sarg - 2: Based on a baseline water hyacinths system that floats offshore. (In 30ft. water depths) A), B), \& C) represent variations in yield. 
Table 5. Estuarine Gracilaria/Ulva Production Costs

\begin{tabular}{|c|c|c|c|}
\hline Case & Grac - IA & Grac - IB & Grac -10 \\
\hline $\begin{array}{l}\text { Facility Size } \\
\text { (Hectares) }\end{array}$ & 5344 & 5344 & 5344 \\
\hline $\begin{array}{l}\text { Yield } \\
\text { (DAFT/acre) } \\
\text { (DAFMT/hectare) }\end{array}$ & $\begin{array}{c}10 \\
(22.4)\end{array}$ & $\begin{array}{c}10 \\
(22.4)\end{array}$ & $\begin{array}{c}15 \\
(33.6)\end{array}$ \\
\hline $\begin{array}{l}\text { Total System Yield } \\
\text { (DAFMT/yr) }\end{array}$ & 119,779 & 119,779 & 179,669 \\
\hline $\begin{array}{l}\text { Capital Investment } \\
\left(1982 \$ \times 10^{6}\right)\end{array}$ & 18.3 & 10.0 & 10.0 \\
\hline $\begin{array}{l}\text { Annual Fuel Cost } \\
\left(1982 \$ \times 10^{6}\right)\end{array}$ & 1.2 & 1.2 & 1.2 \\
\hline $\begin{array}{c}\text { Annual O \& M Cost } \\
\left(1982 \$ \times 10^{6}\right)\end{array}$ & 2.7 & 2.0 & 2.0 \\
\hline $\begin{array}{l}\text { Feedstock Cost } \\
\text { (1984 \$/DAFMT) }\end{array}$ & 53.92 & 41.17 & 27.45 \\
\hline
\end{tabular}

Case Descriptions:

Grac - 1: Based on an estuarine - located system
A) Base case
B) $45 \%$ Reduction in capital investment, $35 \%$ reduction in O\&M costs
C) $50 \%$ increase in yield, $45 \%$ reduction in capital investment, $35 \%$ reduction in O\&M costs 


\subsubsection{Land-Based Gracilaria/Ulva}

The land-based system for cultivation of Gracilaria and Ulva would utilize a much smaller facility size: 100 ha size was used. Yields in the range of 54-78 DAFMT ha' $\mathrm{yr}^{-}$, somewhat higher than the nearshore options, were examined. Table 6 summarizes all the cases; variations in hydraulic retention time and nutrient recycle rates were considered, leading to variations in capital and operating costs. The capital costs vary from $\$ 3.0$ to $\$ 3.3$ million, the operating costs vary from $\$ 0.6$ to $\$ 0.7$ million, and the final feedstock costs from a high of $\$ 226$ to a low of \$|3I/DAFMT. These costs are significantly higher than the other schemes examined, mainly because of the intensive nature of the system. Even in the best case, the $\$ 13 \mid$ production cost is over twice as high as the other, less intensive systems.

Cost for land, construction, plumbing, harvest, labor, and maintenance are all highly system and site specific, but "reasonable" values are assumed. The operation and maintenance cost accounts for $57 \%$ of the total costs, which is very high compared to the other marine options, but is necessary to cover the costs of providing nutrients and carbon.

\subsection{Conclusions}

The results of the production cost analysis are presented in Figure 9 for comparison between concepts. For each concept the production cost ranges from a maximum for the state-of-the-art technology to a minimum for the research improved case. The primary driver for lowering costs and uncertainty is in improving biomass yields. As shown by this analysis increases in yields substantially lowers feedstock costs. As these systems are minimally engineered, little cost benefit is seen from improvements in engineering. The exception may be in harvesting where more efficient harvestors-processors-planters may reduce costs.

The major cost-contribution to the feedstock cost shifts between the different production concepts. The two extremes are represented in Figure 10, which shows the Sargassum adjacent facility as having the highest percentage of costs attributable to capital cost, while the land based Gracilaria/Ulva concept has the highest relative operations and maintenance cost contribution.

As can be seen in Figure 10, the obvious production cost extremes are claimed by the land based Gracilaria/Ulva concept. This is due mainly to the high costs associated with the operation of this energy and nutrient intense cultivation strategy. Land based raceway cultivation will probably have its greatest value in producing crops for specific high value products.

The other three concepts have comparable production costs, depending mainly on yield assumptions. These costs will be used in the next stage of the analysis that evaluates the economics of processing the biomass feedstock into fuels. These final fuel costs will be dependent not only upon the feedstock cost, but also upon the chemical composition of each species, and the processing costs. 
Table 6. Gracilaria/Ulva-Land Based Production Costs

\begin{tabular}{lccccc}
\hline Case & Grac-2A & Grac-2B & Grac-2C & Grac-2D & Grac-2E \\
\hline $\begin{array}{l}\text { Facility Size } \\
\text { (Hectares) }\end{array}$ & 100 & 100 & 100 & 100 & 100 \\
$\begin{array}{c}\text { Yield } \\
\text { (DAFMT/acre) } \\
\text { (DAFMT/hectare) }\end{array}$ & $\begin{array}{c}25 \\
\quad 54)\end{array}$ & $\begin{array}{c}15 \\
(54)\end{array}$ & $\begin{array}{c}25 \\
(54)\end{array}$ & $\begin{array}{c}25 \\
(54)\end{array}$ & $\begin{array}{c}35 \\
(78)\end{array}$ \\
$\begin{array}{c}\text { Total System Yield } \\
\text { (DAFMT/yr) }\end{array}$ & 5400 & 5400 & 5400 & 5400 & 7800 \\
$\begin{array}{c}\text { Capital Investment } \\
\left(1982 \$ \times 10^{6}\right)\end{array}$ & 2.97 & 3.31 & 2.97 & 3.31 & 2.97 \\
$\begin{array}{c}\text { Annual Fuel Cost } \\
\left(1982 \$ \times 10^{6}\right)\end{array}$ & .14 & .20 & .14 & .20 & .14 \\
$\begin{array}{c}\text { Annual O \& M Cost } \\
\left(1982 \$ \times 10^{6}\right)\end{array}$ & .57 & .57 & .50 & .50 & .50 \\
\hline $\begin{array}{c}\text { Feedstock Cost } \\
(1984 \$ / D A F M T)\end{array}$ & 202.15 & 226.13 & 189.19 & 213.38 & 130.98 \\
\hline
\end{tabular}

Case Descriptions:

Grac-2: Based on a land-based production system utilizing saline waters from underground aquifers, which is pumped through channels or raceways.
A) Base case; .I turnovers/day, no nutrient recycle
B) .5 turnovers/day, no nutrient recycle
C) .1 turnovers/day, $50 \%$ nutrient recycle
D) .5 turnovers/day, $50 \%$ nutrient recycle
E) .I turnovers/day, $50 \%$ nutrient recycle, $40 \%$ increased yield 


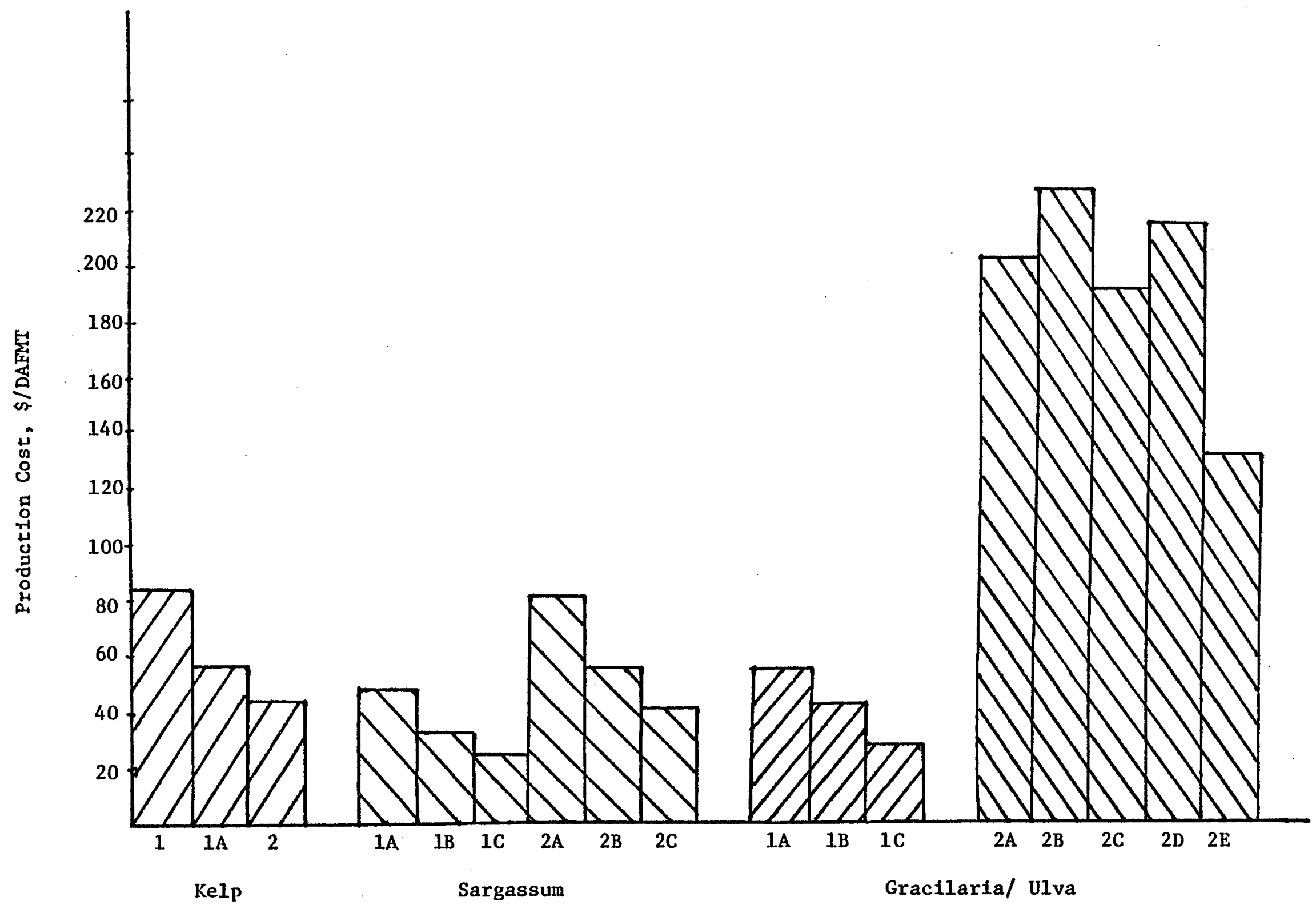

Figure 9. Macroalgal Production Costs 


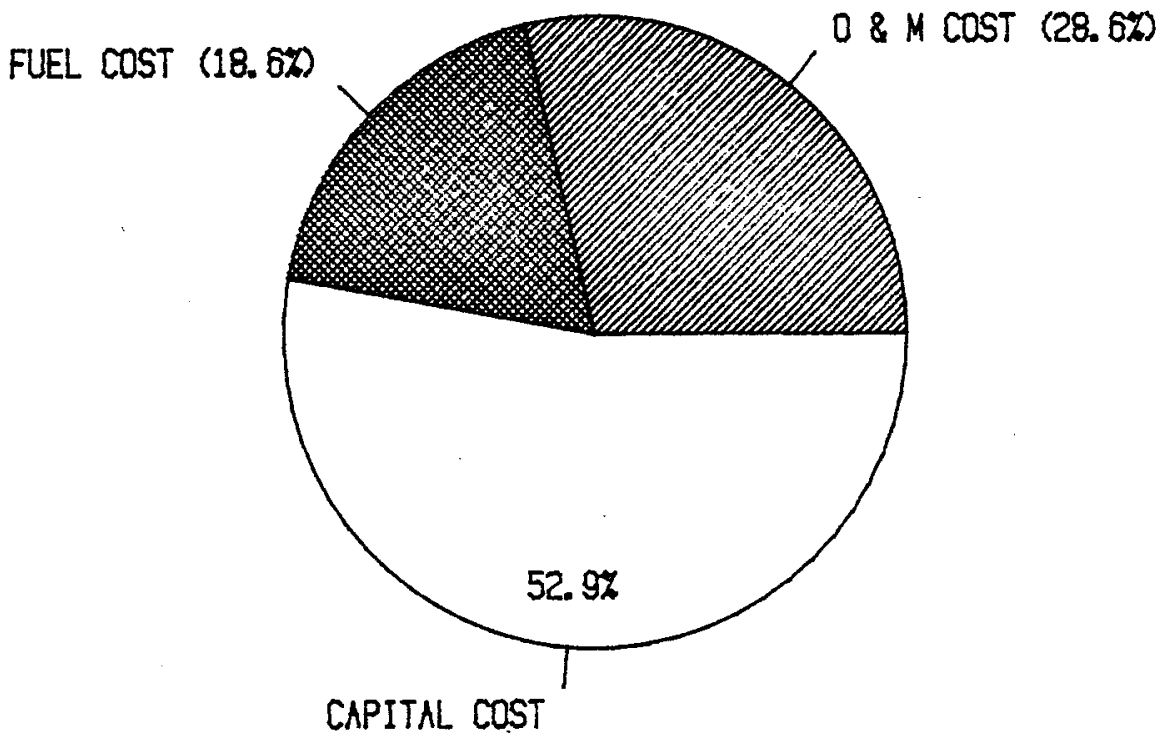

Sargassum Floating Adjacent Facility

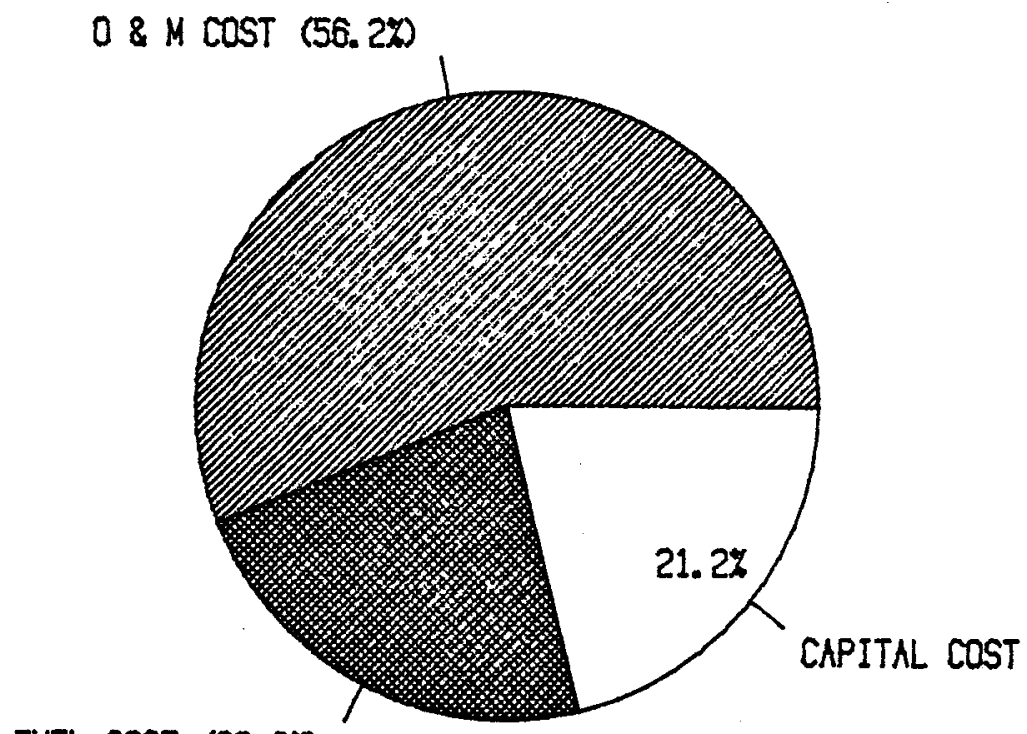

FUEL COST (22. 6x)

Land Based Gracilaria/U1va Base Case

Figure 10. Representative Cost Contribution to Feedstock Cost 


\subsection{BASIC CONCEPTS FOR CONVERSION TO FUEL PRODUCTS}

The major objective of the fuel products portion of this analysis is to determine how best to exploit the chemical composition of the macroalgae feedstocks to produce fuels. The concept of the biomass refinery is introduced. Similar to the typical petroleum refinery, the biomass refinery receives crude feedstock from a culture facility, the feedstock composition is determined by analysis and is then characterized as suitable for producing a specific slate of products. Various processing options may be considered, and the final choice is a function of the feedstock, the seasonal changes in fuel demand, the availability of essential equipment, and, ultimately, economics.

In order to select the best macroalgal feedstocks for energy production, as well as the best fuel options for a particular feedstock, an examination of proximate chemistry must first be made. Based on the chemical characteristics of the macroalgae feedstocks, a series of conversion process options can then be examined. Each of the feedstocks is matched with all the processes considered; the fuel product costs can be determined and compared against each other. Thus, some conclusions can be drawn about the best feedstocks and the best fuel product options available.

\subsection{Proximate Chemistry of Macroalgal Species}

Macroalgae are referred to as belonging to one of three classes: red, green, or brown. Of the species which will be considered here, Kelp (Macrocystis) is a large brown algae which grows attached off the coast of California; Sargassum, which grows floating in tropical waters, is brown; Gracilaria (red) and Ulva (green) both grow unattached and in the bottoms of shallow embayments. Macroalgae consist primarily of carbohydrate and ash, with lesser amounts of protein and lipid. Ash content varies among species from 30 to $50 \%$ of total dry weight (Table 7). Macrocystis was originally harvested in the early 1900's for recovery of potash and iodine salts which are major constituents of the ash; sodium, magnesium, and bromine are also present (Jain, 1983). Lipids, a minor constituent, consist mostly of triglyceride, plus a phenolic-derived compound somewhat analagous to the lignin component of lignocellulose.

Carbohydrate accounts for over $80 \%$ of ash-free dry weight, or $40-55 \%$ of total biomass. The carbohydrate fraction consists of a variety of components. A major one in the browns is mannitol, an alcohol derived from mannose, a hexose (six-carbon) sugar similar to glucose. Another one is algin, a copolymer derived from mannose and gulose (another hexose). A major cell wall structural component of the brown algae, algin is converted into various gums used in the food, pharmaceutical, and textile industries. In the red macroalgae are found the polygalactans (polymers of galactose) agar and carrageenan, which are also recovered and used industrially. Other hexose-derived polysaccharides include fucoidan (from fucose), laminarin (from glucose), and cellulose (from glucose). Tompkins (1981) presents detailed analytical data on carbohydrate content of various algae, while Jain (1983) discusses commercial uses for some of the algal constituents. The fact that the great majority of carbohydrate is ultimately reducible to hexose will be of interest to the examination of ethanol production which follows below.

The methane productivities for the macroalgae (Table 7) were based both on the composition and on knowledge of each species and its potential in optimized USR reactors. In English units, these values were 5.5 standard cubic foot per pound of volatile solids (SCF/lb VS) for Macrocystis, 5.0 SCF/lb VS for Sargassum, and $6.0 \mathrm{SCF} / \mathrm{lb}$ VS for Gracilaria and Ulva. Each conversion rate is felt to be achievable in the short term using that feedstock. 
Table 7. Macroalgae: Composition and Biochemical Profiles

\begin{tabular}{|c|c|c|c|c|c|}
\hline \multirow[t]{2}{*}{ Species } & \multirow[t]{2}{*}{ Macrocystis } & \multirow[t]{2}{*}{ Sargassum } & \multirow[t]{2}{*}{ Ulva } & \multicolumn{2}{|c|}{ Gracilaria } \\
\hline & & & & Baseline & Advanced \\
\hline $\begin{array}{l}\text { Ash (\% of TS) } \\
\text { Volatile (\% of TS) }\end{array}$ & $\begin{array}{l}40 \\
60\end{array}$ & $\begin{array}{l}38 \\
62\end{array}$ & $\begin{array}{l}30 \\
70\end{array}$ & $\begin{array}{l}48 \\
52\end{array}$ & $\begin{array}{l}37 \\
63\end{array}$ \\
\hline $\begin{array}{l}\text { (\% of VS) } \\
\text { Carbohydrate } \\
\text { Protein } \\
\text { Lipid }\end{array}$ & $\begin{array}{l}80 \\
15 \\
5\end{array}$ & $\begin{array}{l}89 \\
8 \\
3\end{array}$ & $\begin{array}{l}85.7 \\
8.6 \\
5.7\end{array}$ & $\begin{array}{c}80 \\
14 \\
6\end{array}$ & $\begin{array}{c}82 \\
12 \\
6\end{array}$ \\
\hline $\begin{array}{l}\text { Energy Content (GJ/DAFMT) } \\
\text { Methane production }\end{array}$ & 19.6 & 18.7 & 19.3 & 19.7 & 19.6 \\
\hline $\begin{array}{l}(\mathrm{SCM} / \mathrm{kg} \text { VS) } \\
\text { Solubles }\left(\% \text { of } \mathrm{CH}_{2} \mathrm{O}\right) \\
\text { Fermentables }\left(\% \text { of } \mathrm{CH}_{2} \mathrm{O}\right)\end{array}$ & $\begin{array}{l}0.34 \\
50 \\
75\end{array}$ & $\begin{array}{l}0.31 \\
17.5 \\
75\end{array}$ & $\begin{array}{l}0.37 \\
25 \\
75\end{array}$ & $\begin{array}{l}0.37 \\
50 \\
75\end{array}$ & $\begin{array}{l}0.37 \\
68 \\
75\end{array}$ \\
\hline
\end{tabular}

${ }^{\mathrm{a}}$ To obtain $\mathrm{MJ} / \mathrm{kg}$ (or $\mathrm{GJ} / \mathrm{mt}$ ) divide Btu/lb by 430.9 .

${ }^{b}$ To obtain $M J / L$ divide Btu/gal by 3,588.

${ }^{\mathrm{C}}$ To obtain SCF/lb divide SCM/kg by 0.06 .

Sources:

Brehany (1983), Habig, et al. (1983), Habig and Ryther (1984). Ryther (1985), Tompkins (1981).

Once alternative fuel products are produced, detailed examination will be required to verify, if not identify, the valuable properties present. Octane enhancement is a good example of how a renewable fuel (ethanol) can improve a particular property of the nonrenewable fuel (gasoline) to which it is added. The problem is considerably more complex than developing new fuel products one at a time. However, an alternative fuel with one attractive feature, for example ethanol or methanol with a high octane value, would have an opportunity for market entry, especially where it would complement fuels derived from conventional resources and processes.

\subsection{Conversion Processes Examined}

\subsection{Methane}

The discussion of processes examined begins with anaerobic digestion for the production of methane. Anaerobic digestion is the one process by which essentially all of the aquatic feedstock could be converted into a single fuel product. Methane, the primary constituent of natural gas, is widely used as both a fuel and as a chemical feedstock. Since under normal conditions it is a gas and therefore bulky to handle, its use as a transportation fuel has been limited. However, natural gas boilers and combustion turbines are in wide use. Liquefied natural gas (LNG), with increased density, has begun to be used as a transportation fuel. 
An anaerobic digester typically contains microbial populations to convert a variety of organic substrates to methane and carbon dioxide. Few problems have been encountered in the adaptation of macroalgae feedstocks to anaerobic digestion; in fact, macroalgae have already been studied widely in this context (Bird 1984; Habig and Ryther 1984; Habig et al. 1984). The major technical concern at this point is the continuing development of more efficient digesters. The analysis presented here is based on the upflow solids reactor (USR), which has been developed more recently, and which might offer better conversion efficiencies and shorter residence times than the plug-flow and other types.

The primary digester product, usually referred to as biogas, is not pure methane, but contains large amounts (typically 40\%) of carbon dioxide, plus trace amounts of water and hydrogen sulfide. The water, sulfur, and nitrogen components must be removed prior to use, but removal of the $\mathrm{CO}_{2}$ is optional. If the gas is to be burned on site, $\mathrm{CO}_{2}$ removal is not required. On the other hand, the gas will have a lower Btu content per cubic meter, so a larger volume of gas is required for the same heat output. Direct use of this medium-Btu gas, as it is commonly called, is still probably cheaper than $\mathrm{CO}_{2}$ removal in small-scale applications. However, when large volumes of gas are sold to a pipeline company or gas utility, $\mathrm{CO}_{2}$ removal will be required. This is accomplished using any number of gas absorption processes, with water, sodium carbonate, and ethanolamines being the most popular absorbents. From land-based culture systems, carbon dioxide recovery and recycle to the culture system would be essential; the methane would then be in the form of high-Btu gas suitable for either pipelines or further chemical processing.

\subsubsection{Ethanol}

Ethanol is the highest-volume product, fuel or otherwise, produced commercially by biological fermentation. In the beverage and fuel industries, the primary substrate is starch from corn or other grains, although any carbohydrate source is suitable for conversion to sugars and subsequently to ethanol.

The ethanol production process presented here has been adapted from a corn-based process (Raphael Katzen Associates 1980; Technical Insights Inc. 1980). Some details of the process would change for slurries of aquatic biomass; for example, the mash cooking step has somewhat higher energy requirements because of the amount of water present. The fermentation products are separated by distillation, and all nonfermentables are discharged out the bottom of the still. From a corn substrate, this material would be dried and sold as distiller's dried grains (DDG), slop, or stillage. A similar product could be recovered from aquatic species. The stillage from an algal ethanol plant might be usable as a food or feed product similar to soybean meal; species-specific research is required for characterization of the protein product.

One disadvantage of macroalgae is that typically their polysaccharides are in the form of starch, so the sugars are easily accessible for yeast fermentation. The fibrous and colloidal polysaccharides of macroalgae, on the other hand, may not be so easily accessible. In this analysis a conservative approach was taken: a mild acid hydrolysis block, similar to that which would be used for a lignocellulosic feedstock, was added to the ethanol production system (Figure (I). Such a pretreatment is undoubtedly more severe (and more expensive) than necessary, but would certainly convert the fibers to soluble sugars. A filtration and/or washing step would remove the soluble carbohydrates, after which the hydrolysis would be done. All sugars could then be treated as solubles and fermented together. Downstream processing would be identical to the microalgalbased ethanol facility. 
The major issues concerning ethanol production from aquatic species are the maximum carbohydrate content that can be achieved and the portion of the carbohydrate that could be converted to fermentable sugars and then to ethanol. Carbohydrate does not vary widely (as a percentage of ash-free dry weight), but the soluble fraction varies widely among species, from below $20 \%$ of total carbohydrate in Sargassum to almost $70 \%$ in some Gracilaria. The $\mathrm{C}_{6} / \mathrm{C}_{5}$ ratio is used here as a good indicator of the percent fermentable figure of each feedstock. Very small amounts of five-carbon sugars have been identified in macroalgae; a range of 75 to $90 \%$ fermentables can be estimated conservatively in this analysis.

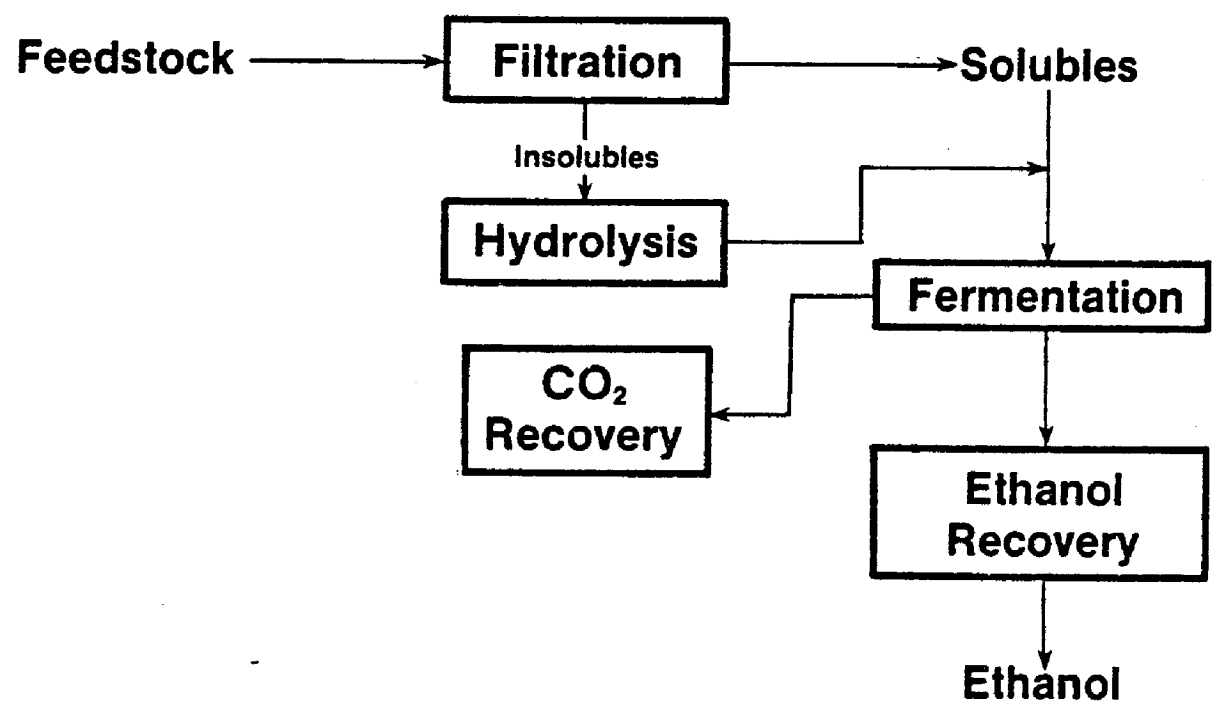

Figure 11. Ethanol Production from Macroalgae 


\subsection{CONVERSION PROCESS ECONOMICS}

Now that the processes for conversion of macroalgae into fuel products has been examined, the comparative economics of the process options can be considered. The results presented were developed from simple models and are of screening-quality: admittedly subject to a good deal of uncertainty. One basic assumption is that the algal refinery is located near the algal culture facility, and sized to match its capacity. In addition, some cases are examined in which the refinery is sized to serve ten culture facilities, thereby realizing significant improvements in conversion costs and thus in the final selling price of the product.

Once the fuel product costs for the various options have been determined, they must be compared to costs of the nonrenewable fuels being replaced. The concept developed by the Department of Energy to address this question is that of the cost goal. The cost goal for a renewable resource-derived fuel product is the cost which is just equal to that of the competing nonrenewable fuel product(s) at a specified time. The analysis uses real 1984 dollars (i.e., with no inflation factors added) throughout. The cost goals for each fuel product are based on a series of energy price projections developed by DOE's Office of Policy, Planning and Analysis (1983) in support of the National Energy Policy Plan (NEPP).

Based on the state of developement of the technologies evaluated in this study, the time chosen for macroalgae-derived fuel products is the year 1995. Cost goals for the important nonrenewable fuels as well as the macroalgae-derived fuels are shown in Table 8. To facilitate the comparison of the cost of each algae-derived fuel product with the cost goal, we also introduce the concept of normalized cost (note 2 on Table 8). Any algae-derived fuel product with a normalized cost less than or equal to 1.0 is considered to have met its cost goal. 
Table 8. Fuel Cost Goals

YEAR

1995

LOW HIGH

World Oil Price (\$/BBL) $\quad 30.30 \quad 59.50$

$\begin{array}{lll}(\$ / G J) & 4.95 & 9.73\end{array}$

Natural Gas (\$/GJ)

Industrial Sector

$4.40 \quad 7.08$

Gasoline (Alcohols)

(\$/GJ)

$(\$ / g a l)$

$10.27 \quad 15.54$

$\begin{array}{ll}1.35 & 2.05\end{array}$

Ethanol

$(\$ / g a l)$

$0.91 \quad 1.38$

Notes:

Volumetric heating values are higher (gross) heating valves, per NEPP IV convention: Crude Oil $=5.810^{\circ} \mathrm{Btu} / \mathrm{BBL}$

Gasoline $=125,000 \mathrm{Btu} / \mathrm{gal}$

Ethanol $=84,000 \mathrm{Btu} / \mathrm{gal}$

2 Normalized cost $=\frac{\text { Estimated Fuel Production Cost }}{\text { Cost goathithis }}$

3 SI Conversions:

Cost goal (High)

To obtain $\mathrm{MJ} / \mathrm{kg}$ (or $\mathrm{GJ} / \mathrm{t}$ ) divide Btu/lb by 430.9 .

To obtain $\mathrm{MJ} / \mathrm{L}$ divide Btu/gal by 3,588.

To obtain $\$ / G J$ divide $\$ / 10^{6}$ Btu by 1.055 .

Source: Department of Energy 1983. 


\subsection{Kelp}

Using the baseline kelp cultivation strategy, a kelp-to-methane facility dedicated to the 5340 ha would produce $1.2 \times 10^{15} \mathrm{~J} / \mathrm{yr}$ of methane at a cost of $\$ 10.70 / \mathrm{GJ}$ $\left(\$ 11.30 / 10^{6} \mathrm{Btu}\right)($ Table 9). The normalized cost for this case is 1.5 . With the advanced strategy, $2.6 \times 10^{15} \mathrm{~J} / \mathrm{yr}$ would be produced at a cost of $\$ 6.60 / \mathrm{GJ}$, for a normalized cost of 0.94 just meeting the cost goal. Most of this saving is due to the lower feedstock cost (from \$84 to \$44/DAFMT); some improvements are also realized in capital cost of gas processing from economies of scale.

Looking at the economics of ethanol production, a facility taking feedstock from a baseline kelp production facility would produce 8.8 million gal of ethanol per year at a cost of $\$ 2.40 / \mathrm{gal}$ (normalized cost of 1.8). This ethanol yield is based on $50 \%$ solubles content and $75 \%$ fermentables content in the crude kelp feed. With improvements in proximate chemistry optimized for ethanol production $(60 \%$ solubles content plus $90 \%$ fermentables), the ethanol cost would be lowereed to $\$ 1.30 / \mathrm{gal}$, enabling the advanced case also to just meet the cost goal. All normalized costs are presented graphically in Figure 12.

\subsection{Sargassum: Adjacent}

For Sargassum, the adjacent strategy will be considered first. As in the kelp discussion above, fuel costs were estimated for the baseline and advanced cases, but not the intermediate one. From the baseline case (IODAFMT ha $\mathrm{yr}^{-1}$ ) methane yield is $1.1 \times 10^{15} \mathrm{~J} / \mathrm{yr}$, similar to the Kelp baseline case (Table 9), but the cost is $\$ 7.60 / \mathrm{GJ}$, which is substantially lower than for Kelp. Lower methane costs are primarily the result of the lower feedstock cost: the lower digestibility of Sargassum is compensated by the lower feed cost. In the advanced case, with a doubled productivity, methane cost decreases to $\$ 4.80 / G J$, equivalent to a normalized cost of 0.67 .

Ethanol production in the baseline case is $8.8 \mathrm{million} \mathrm{gal} / \mathrm{yr}$, the same as for the baseline Kelp; the cost of $\$ 2.40 / \mathrm{gal}$ is essentially the same. Compared to Kelp the lower feedstock cost of the Sargassum just compensates for the higher processing costs: with a solubles content of only $17.5 \%$ of total carbohydrate, the acid hydrolysis capacity is much larger than for the other macroalgae. The advanced production strategy could achieve an ethanol yield as high as 21 million gal/yr, with costs as low as $\$ 1.60 / \mathrm{gal}$ (normalized cost of 1.1 ). This cost is again slightly higher than Kelp because of the much lower solubles content.

\subsection{Sargassum: Nonadjacent}

The nonadjacent cultivation strategy for Sargassum uses higher production facility sizes, resulting in higher system yields (but also incurring higher costs). These higher costs are carried over to higher fuel product costs in all cases (Table 9). Methane production ranges from 1.5 to $2.9 \times 10^{15} \mathrm{~J} / \mathrm{yr}$, with associated costs of $\$ 11.20$ to $\$ 6.60 / \mathrm{GJ}$ Ethanol yields range from 12.2 to 29.3 million $\mathrm{gal} / \mathrm{yr}$, with product costs ranging from $\$ 2.70 / \mathrm{gal}$ to $\$ 1.70 /$ gal. Only the methane option meets the cost goal, and then only in the advanced case. Based on the results of this analysis, the adjacent production strategy is the better way to go for Sargassum. 


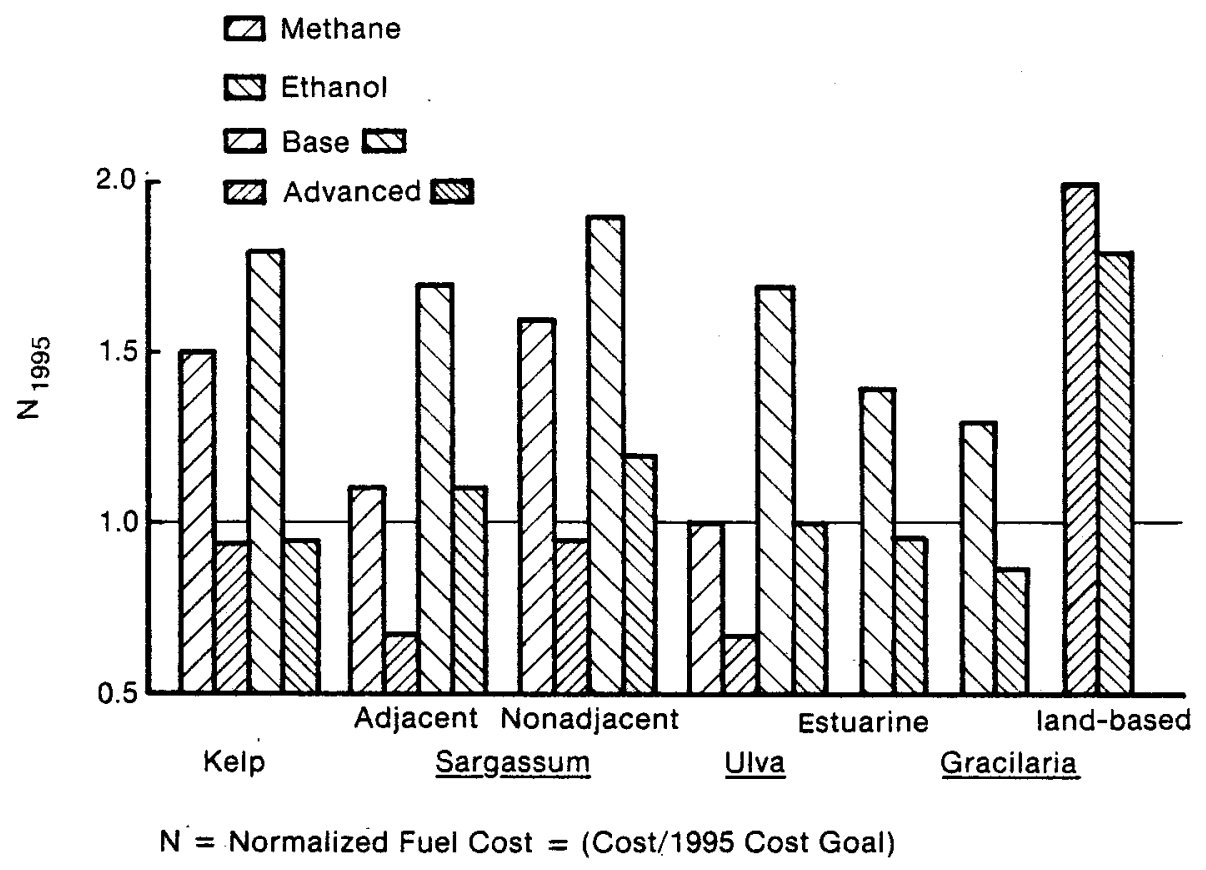

Figure 12. Macroalgae Normalized Fuel Costs 


\subsection{Ulva: Estuarine}

Of the macroalgae that can be cultivated using the estuarine techniques, Ulva will be discussed first. Up to $1.3 \times 10^{15} \mathrm{~J} / \mathrm{yr}$ of methgne at a cost of $\$ 7.20 / \mathrm{GJ}$ could be produced from baseline strategy, while $1.9 \times 10^{15} \mathrm{~J} / \mathrm{yr}$ could be produced in the most advanced case, selling for $\$ 4.60 / G \mathrm{~J}$ (Table 9). These are the lowest estimated methane costs to date, primarily because of the higher digestibility of this species.

Ethanol costs are among the lowest but higher hydrolysis costs are required with a solubles concentration of only $25 \%$. Baseline ethanol production is 8.4 million gal, at a cost of $\$ 2.40 /$ gal. Doubling the feedstock productivity in the advanced case. as well as increasing both the solubles (to $50 \%$ ) and fermentables (from 75 to $90 \%$ ) increases ethanol production to $16.9 \mathrm{million} \mathrm{gal} / \mathrm{yr}$ and decreases costs to $\$ 1.40 / \mathrm{gal}$.

\subsection{Gracilaria: Estuarine}

Methane production yields and costs are estimated to be equal for Gracilaria and Ulva (Table 9). Due to differences in proximate chemistry, however, Gracilaria has greater potential as a feedstock for ethanol production. Gracilaria has much higher solubles content, so that, although total carbohydrate is lower, ethanol yield is higher: 8.8 million $\mathrm{gal} / \mathrm{yr}$ at $\$ 2.00 / \mathrm{gal}$. Increasing fermentables from 75 to $90 \%$ (with constant solubles content of $50 \%$ ) along with the highest feedstock production yield gives an ethanol production of $15.8 \mathrm{million} \mathrm{gal} / \mathrm{yr}$ with a cost of $\$ 1.30 / \mathrm{gal}$.

If further improvement of Gracilaria's proximate chemistry could be achieved (refer to Table 7), the ethanol production potential would be further enhanced. With the improved carbohydrate content (from 80 to $82 \%$ ) and improved solubles content (from 50 to $68 \%$ ), the ethanol production would be $9.6 \mathrm{million} \mathrm{gal} / \mathrm{yr}$ with costs of $\$ 1.75 / \mathrm{gal}$ in the baseline case (Table 9). Taking the advanced feedstock production strategy (yield of 15 DAFMT ha ${ }^{-1} \mathrm{yr}^{-1}$ plus improvements in capital and operating costs) plus increasing the solubles content to $90 \%$ leads to ethanol production of $17.3 \mathrm{million} \mathrm{gal} / \mathrm{yr}$ at a cost of $\$ 1.20 / \mathrm{gal}$, for a normalized cost of 0.87 .

\subsection{Gracilaria: Land-based}

The land-based option was shown in Section 3 to be the most expensive option for macroalgae cultivation; this section will show such an option not to be economically feasible for fuel production. Taking the most advanced production strategy, with a yield of 78 DAFMT ho- $\mathrm{yr}^{-1}$, and adding the further enhancement of scale economies (e.g., by sizing the ethanol facility to receive feedstock from not just one but from ten of the 100-ha cultivation facilities), the lowest methane production cost would be $\$ 14.30 / G \mathrm{~J}$ over a production of $7.5 \times 10^{14} \mathrm{~J} / \mathrm{yr}$ (Table 9). This case also includes the improved carbohydrate composition. For ethanol production, the lowest price achievable is $\$ 2.50 / \mathrm{gal}$, not in the range of the nearshore and adjacent strategies. When other options such as these are available, the land-based option will not be competitive. 


\subsection{CONCLUSIONS}

Macroalgae are unique feedstocks that could be competitive sources of renewable liquid or gaseous fuels by the early 21 st century. Their most important attributes to be exploited are their potentially high biomass productivities, their high yields of fermentable carbohydrates, and especially their low biomass production costs.

Even at this preliminary stage of evaluation, two processes have been identified which offer potential for commercial development. Macroalgae could be anaerobically digested to produce methane, or their large store of carbohydrates could be aerobically fermented to produce ethyl alcohol. Although in the baseline cases (reflective of current state-ofthe-art technology), competitive fuel production cannot be achieved, methane from Macrocystis, Sargassum, Gracilaria, and Ulva species could be cost-competitive in the mid 1990's with certain production and conversion improvements. Ethanol production from Macrocystis, Gracilaria, or Ulva could become competitive during the same time period, again, with the achievement of yield and conversion improvements.

Although macroalgal cultivation technology has not been successfully practiced over the scale required for energy production, yields could be made reliable. The processes for conversion of macroalgae feedstocks to fuels have reached a more mature stage of development. Both production and conversion require substantial continued research efforts before commercialization can occur. The technology improvements required for commercialization of macroalgal fuel production options would be achieved through research directed at species improvement and development of optimized, integrated conversion processes. 


\subsection{REFERENCES}

Ashare, E., 1981, "Analysis of systems for purification of fuel gas,", in Wise, D.L., Fuel gas production from biomass, Vol. II, Boca Raton, FL: CRC Press, p. I.

Ashare, E., and E. H. Wilson, 1979, Analysis of Digester Design Concepts, USDOE COO2991-42, Cambridge, MA: Dynatech $R$ and $D$ Laboratory.

Bird, K.T., 1984, An historical perspective on economic and systems costs of kelp cultivation for bioconversion to methane, Chicago, IL: Gas Research Institute, in press.

Bird, K.T., 1985a, Algal Biomass Economics, Technical note to author, Chicago, IL: Gas Research Institute.

Bird, K. T., et al, 1985b, Macroalgal Cultivation for Food, Chemicals and Energy, Chicago, IL: Gas Research Institute, In Press.

Brehany, J.J., 1983. An economic and systems assessment of the concept of nearshore kelp farming for methane production, R.M.Parsons Co., Final Report for Gas Research Institute, No. GRI 82/0067, Chicago, IL.

Cowley, 1. D. and D. A. J. Wase, 1981, "Anaerobic Digestion of Farm Wastes; a review-Part 1," Process Biochem., Aug/Sept., p. 28.

Department of Energy, Office of Policy, Planning and Analysis, 1983, Energy Projections to the Year 2000, Report No. DOE/PE-0029/2, Washington, D.C.

Habig, C., and J.H.Ryther, 1984, "Some correlations between substrate compositions and biogas yields," in Energy from Biomass and Wastes VIII, Institute of Gas Technology, Chicago, IL, P. 817 .

Habig, C., T.A.DeBusk, and J.H.Ryther, 1984, "The effect of nitrogen content on methane production by the marine algae Gracilaria tikvahiae and Ulva sp." Biomass, Vol.4, p.239.

Hill, A., D. Feinberg, R. Mcintosh, B. Neenan, and K. Terry, 1984, Fuels from Microalgae: Technology Status, Potential, and Research Issues, SERI/SP-23/-2550 (draft), Golden, CO: Solar Energy Research Institute.

Huguenin, J. E., 1976, "An Examination of Problems and Potentials for Future LargeScale Intensive Seaweed Culture Systems", Aquaculture, Vol. 9313.

International Trade Commission, 1982, Synthetic Organic Chemicals, U. S. Production and Sales, 1981, Washington, D.C.

Jain, K., 1983, A technical and economic evaluation of production of chemicals as byproducts/co-products of methane production from kelp, GE-BIO-1868, King of Prussia, PA: General Electric Co.

McCallum, P.W., T. J. Timbario, R. C. Bechtold, and E. E. Ecklund, 1982, "Alcohol Fuels for Highway Vehicles", Chemical Engineering Progress, Vol. 78 (8) p.52. 
Raphael Katzen Associates, 1980, "Grain Motor Fuel Technical and Economic Assessment Study" in Paul J. K., ed., Large and Small Scale Ethyl Alcohol Manufacturing Processes from Agricultural Raw Materials, Noyes Data Corp., Park Ridge, N. J.

Ryther, J. H., 1982, Cultivation of macroscopic marine algae and freshwater aquatic weeds, Report to SERI, subcontract \#XR-9-8133-1, Feb. 1982, 142pp.

Ryther, J. H., et al, 1984, Cultivation and Conversion of Marine Macroalgae, Harbor Branch Institution, Final Subcontract Report to SERI, SERI/STR-231-2360.

Ryther, J.H., 16 January 1985, letter to R.Mclntosh.

Shang, 1976, Economic Aspects of Gracilaria Culture in Taiwan.

Technical Insights, Inc., 1980, Biomass Process Handbook, Fort Lee, NJ.

Tompkins, A.N., 1981, Marine Biomass Program, Annual Report for 1980, SERI Contract No. XK-0-9350-1. 
Table 9. Macroalgae Fuel Production Options

Kelp $\quad \underline{\text { Sargassum }} \quad \underline{\text { Ulva }} \quad$ Grocilaria $\quad \underline{\text { Graciloria }}$

\begin{tabular}{|c|c|c|c|c|c|c|c|c|c|c|c|c|c|}
\hline \multirow{3}{*}{$\begin{array}{l}\text { Concept } \\
\text { METHANE }\end{array}$} & \multirow{2}{*}{\multicolumn{2}{|c|}{ Nearshore }} & \multirow{2}{*}{\multicolumn{2}{|c|}{ Adjocent }} & \multirow{2}{*}{\multicolumn{2}{|c|}{ Nonadjocent }} & \multirow{2}{*}{\multicolumn{2}{|c|}{ Estuarine }} & \multicolumn{4}{|c|}{ Estuarine } & \multirow{3}{*}{$\begin{array}{c}\begin{array}{c}\text { Land-Basec } \\
\text { Improved } \\
\text { Compositio }\end{array} \\
\text { Advanced }^{\mathrm{a}}\end{array}$} \\
\hline & & & & & & & & & \multicolumn{2}{|c|}{$\begin{array}{l}\text { Baseline } \\
\text { Composition }\end{array}$} & \multicolumn{2}{|c|}{$\begin{array}{l}\text { Improved } \\
\text { Composition }\end{array}$} & \\
\hline & Base & Advanced & Base & Advanced & Base & Advanced & Base & Advanced & Base & Advanced & Base & Advanced & \\
\hline $\begin{array}{l}10^{15} \mathrm{~J} / \mathrm{yr} \\
\text { Methane cost, \$/GJ } \\
\text { Normalized cost }\end{array}$ & $\begin{array}{c}1.2 \\
10.70 \\
1.5\end{array}$ & $\begin{array}{l}2.6 \\
6.60 \\
0.94\end{array}$ & $\begin{array}{c}1.1 \\
7.60 \\
1.1\end{array}$ & $\begin{array}{l}2.1 \\
4.80 \\
0.67\end{array}$ & $\begin{array}{l}1.5 \\
11.20 \\
1.6\end{array}$ & $\begin{array}{l}2.9 \\
6.60 \\
0.94\end{array}$ & $\begin{array}{l}1.3 \\
7.20 \\
1.0\end{array}$ & $\begin{array}{l}1.9 \\
4.60 \\
0.66\end{array}$ & $\begin{array}{l}1.3 \\
7.20 \\
1.0\end{array}$ & $\begin{array}{l}1.9 \\
4.60 \\
0.66\end{array}$ & $\begin{array}{l}1.3 \\
7.20 \\
1.0\end{array}$ & $\begin{array}{l}1.9 \\
4.60 \\
0.66\end{array}$ & $\begin{array}{c}0.75 \\
14.30 \\
2.0\end{array}$ \\
\hline
\end{tabular}

\section{ETHANOL}

\begin{tabular}{|c|c|c|c|c|c|c|c|c|c|c|c|c|c|}
\hline $\begin{array}{l}10^{6} \mathrm{gal} / \mathrm{yr} \\
\text { Ethanol cost, \$/gal } \\
\$ / \mathrm{GJ} \\
\text { Normalized cost }\end{array}$ & $\begin{array}{l}8.8 \\
2.40 \\
27.1 \\
1.7\end{array}$ & $\begin{array}{l}24.5 \\
1.30 \\
14.7 \\
0.95\end{array}$ & $\begin{array}{c}8.8 \\
2.40 \\
26.60 \\
1.7\end{array}$ & $\begin{array}{c}21.0 \\
1.60 \\
18.10 \\
1.1\end{array}$ & $\begin{array}{c}12.2 \\
2.70 \\
30.50 \\
1.9\end{array}$ & $\begin{array}{l}29.3 \\
1.70 \\
19.20 \\
1.2\end{array}$ & $\begin{array}{c}8.4 \\
2.40 \\
26.80 \\
1.7\end{array}$ & $\begin{array}{l}16.9 \\
1.40 \\
15.80 \\
1.0\end{array}$ & $\begin{array}{c}8.8 \\
2.00 \\
22.60 \\
1.4\end{array}$ & $\begin{array}{c}15.8 \\
1.30 \\
15.00 \\
0.96\end{array}$ & $\begin{array}{l}9.6 \\
1.75 \\
19.80 \\
1.3\end{array}$ & $\begin{array}{c}17.3 \\
1.20 \\
13.40 \\
0.87\end{array}$ & $\begin{array}{c}7.5 \\
2.50 \\
28.20 \\
1.8\end{array}$ \\
\hline
\end{tabular}

a Optimized scale: Conversion focility size $=10 \times$ feedstock production facility. 